\title{
The Roles of Parent and Teacher on Children Attitude Development to Avoid Bullying Behavior in Early Childhood
}

\author{
Putu Eka Sastrika Ayu \\ STAH N Mpu Kuturan Singaraja, \\ Email: ayu mas89@yahoo.com
}

\begin{abstract}
Family takes important influences on the education of children's moral and personality development. Families especially parents are the main agencies to teach children new things as well as goodness or badness. Early family education should include three aspects namely cognitive, affective and psychomotor aspects. In early family education, parents should impart honest behaving, polite speaking, and responsibility-taking. In this early family education, educational interaction occurs firstly and foremost to the children who would become the foundation of their further education. Cultivating children's attitudes should be carried out by school teachers. There are several roles that can be implemented by the teacher namely; as a model, mentor, coach, motivational speaker, and evaluator. The role of teachers as educators (nurturer) are the roles that are associated with the duties of assistance and encouragement (supporter), the tasks of supervision and coaching (supervisor) as well as tasks related to disciplining children the child was being well behaved against the school rules and norms of life in the family and society. By optimizing the role of parents and teachers in the cultivation of the attitude, then it will be able to reduce bullying behavior in early childhood. The children's experiences with bullying will give long term impacts. For the children having bullying victims, the experience will be a nightmare that never disappears from their memories.
\end{abstract}

Keywords: attitude forming; bullying behavior; early childhood.

\section{INTRODUCTION}

There are three cores in educational environments, namely (1) family, (2) school, and (3) community, in which the three environments can not separate one into other ones. Furthermore, family, as one of the three educational environments cores, is a place of the first and foremost education. This first education can be viewed as a foundation of the further subsequent developments, thus educators need to act carefully, if it is not, the impact could give less good on further children's subsequent

developments. In the Republic of Indonesia Acts Number 20 of the year 2003 on the National Education System, article 7 paragraph 1 stated that "parents participate in selecting a unit of education and obtain information about the development of his child". While that article 7 paragraph 2 states that "the parents of the age of compulsory education, the obligation to provide primary education to their children". Therefore, family, as the most responsible education for their 
children, should always pay attention and guide their children, in particular, the guidance and education of the children's characters associated with itself.

Suhartono (2013) stated that only in the family the education is cultivated, then in schools, it grows likely a lush tree grows up into fruitful in the community lives. It can be confirmed that the existential aspects of education are families, schools, and communities with their respective educational roles. Furthermore, Suhartono (2013) stated that family as a place of cultivating education, consequently, the family obligation is not any supernatural to maintain, build, and develop the seeds of education in order to later be able to bear the values that beneficial for the advancement of life. Fadlillah (2012) also stated that the family environment is an environment for children, any behavior or development that appears on children's self will be modeled on their parents.

However, the role of parents in early childhood education is not implemented. It can be seen from the data based on the year 2006 that the National Children Commission reported the children violence victims including 1,124 485 sexual and physical violence as well as 433106 psychic acts of violence. Of that number, $23.95 \%$ of crimes in children occurred within families like physical violence perpetrated on a child, parental abandonment of children, sexual violence in early childhood, not even a little bit of a parent who dares to kill toddlers.

Early childhood is the future investment for the family and the nation. Later, early childhood will be those who will build the nation of Indonesia to become a developed nation and not be left behind from other Nations. In other words, the future of the nation is largely determined by the education given to early childhood. In Indonesia, the education that leveled for children aged 0-6 years is known as early childhood education (ECE). Early childhood education became an important education for one child. This relates to periods of growth and development of the child's brain that was up to $80 \%$ at the age of 6 years. At the age, anything that accepted by the children will be able to give a strong and durable trace. It means that false in educating children would provide a long term negative effect that is hard to be repaired (Slamet Suyanto, 2005:2).

Imagine if early childhood that should grow up with positive attitudes, attitudes that are in accordance with the expectations of the national educational goals, however, should be inhibited with the advent of bullying behavior in early childhood. According to Coloroso (2003), bullying is a hostile act did consciously and deliberate aimed at hurting, like the scare through threats of aggression and inflicting terror. Including also actions which meant nor spontaneous, real or are barely perceptible, at before someone or on the back of a person, it is easy to be 
identified or veiled behind friendships, committed by a child or group the child.

So it can be inferred that the bullying behavior is repeated negative actions performed consciously and deliberate that it intends to cause discomfort or hurts others. Bullying is the most common type of aggression and casualties experienced by the children of school age (O'Brennan, Bradshaw, \& Sawyer, 2009). Bullying occurs in all age levels, but began to increase in late elementary school, peaks in middle school, and generally declined in high school. Bullying affects both boys and girls. Boys more often engage in physical aggression (Liu \& Graves, 2011).

The impact can be caused due to bullying behavior is feeling depressed, such physical pain (headache, sore throat, flu, coughs, chapped lips, and pain in the chest), while the psychological impact that occurred on in the form of declining confidence (self-esteem), feel ashamed, trauma, fear of the school marked by refusing to go to school (school phobia), fear of social (social phobia), even the tendency to want to commit suicide (it has TI, 2008 and Riauskina, 2005). The researchers found that $78 \%$ of teens who commit suicide often have the behavior of bullying school and in cyberspace, while $32 \%$ of teenagers who are experiencing behavioral bullying mood disorders (Destriyana, 2012). Bullying behaviors if left unchecked will continue to be bad for physical or psychological conditions. The results of the research conducted by
Gendrowiyono (2013), learning the values of tolerance effect in improving the social skills of students, so a good tolerance with children will have good social skills in the disappear adapt social environment so that it is not easy doing the bullying behavior. Not only that, but the role of parents in the home is also very important. As parents should be able to create good communication with children and to provide children with an understanding of religion and imparts an attitude.

Sejiwa (2008) stated one factor causing the occurrence of bullying behavior is family. In the family, all forms and ways of cultivating rules or attention is given to children. The social development of children is firstly instilled by parents within the family through the rules, attitudes, and actions that are seen by the children, where their parents are figured as their role model. Thus, the role of parents in cultivating children's attitude is very important. The cultivation of the attitude in early childhood education has a very important role in building the children's character early on through conditioning and example. Planting this attitude becomes a top priority compared with the development of knowledge and skills. In 2013 the competency development ECE curriculum attitude covers all aspects of development, meaning that the stance was in religious values and moral aspects, physical, cognitive, social and motor skills - emotional, language and art. The structure of the curriculum is the competency 
development attitude of ECE 2013 includes spiritual attitude competency and social attitudes. This article will discuss more broadly about the role of parents in the cultivation of the attitude to avoid bullying behavior in early childhood.

\section{DISCUSSION}

Early childhood is a critical period for the formation of one's character. The cultivation of the attitude early on is the key to building the nation. At the age of 0-6 years, the brain is growing very fast up to $80 \%$. At the age of the brain receive and absorb various kinds of information quickly so that what is given on the child will be absorbed nicely and will apply it in their lives. Children's experiences in the first year of life determine the quality in the future. Children are the generation that will determine the fate of the nation later in the day. Children's characters that were formed since the now will largely determine the character of the nation later in the day.

Based on the Republic of Indonesia Acts No. 20 the Year 2003 of the national education system about early childhood education written on article 28 paragraph 1 of which reads in early childhood education for children from birth up to 6 years old and is not the requirements to adhere to basic education ". Next chapter 1 article 1 paragraph 1 confirmed that early childhood education is an effort of construction which is aimed at children from birth until the age of 6 years are done through the awarding of educational stimulation to help the growth and the development of physical and spiritual so that children have preparedness in entering further education (Mone, USPN,2004:4).

The development of children's social behavior is marked by the existence of their interests in the activities together with their friends. It can enhance a strong desire to be accepted as a member of a group, and they will feel unsatisfaction without any friend. Children are no longer satisfied to play alone at home or with siblings or doing activities with family members of the child who wants to simultaneously his friends and will feel lonely and unsatisfied when not with friends. Two or three friends aren't enough for him. Children want to along with his group, because only thus there are enough friends to play and work out, and can deliver the excitement. Since the child enters school until puberty, wants to be with and accepted for the group is becoming increasingly strong. This, apply for either boys or girls. The social environment is the interaction between society and the environment. Nowadays, it is a tendency some children act bullying. Rigby (2002) defined bullying as the emphasis or repeated suppression, psychologically or physically against someone who has less power or authority by a person or group of stronger people. Meanwhile, Elliot (2005) defines bullying as acts done by someone intentionally make others afraid or threatened. Bullying causes victims to feel intimidated, threatened or at least not unhappy. A widely accepted definition is made Olweus 
(2004) States that students who are doing the bullying are when the students repeatedly and at all times behave aggressively towards one or more other students. negative actions here is when someone intentionally injures or attempt to injure, or make someone uncomfortable. The point indirectly implied in the definition of aggressive behavior. Murphy (2009) perceives bullying as the desire to hurt and most must involve an imbalance of power and the person or group who became a victim is powerless and this happened regularly and treatment being attacked unfairly.

If the bullying behavior is not addressed soon, it will produce a generation of negative, then it behaves correctly as a parent and teacher to optimize its role in tackling bullying behavior in early childhood. Because of the positive character of the children will be well-formed in the process of growing if they get enough space to express themselves freely. The success of someone in the community is largely determined by emotional intelligence $(80 \%)$, only $20 \%$ of cognitive intelligence (Daniel Goleman). At the age of childhood or commonly referred to psychologists as the age of gold (the golden age) proved very influencing ability children in developing its potential. The results showed that about 50 percent of adult intelligence diversity already occurred when the child was four years old. The increase in the next 30 percent occurred at the age of eight years, and the remaining 20 percent in the mid-or at the end of the second decade. Results of the study 13 factors supporting success in the world of work depend on the character of a person. Character education is indeed very important to start early on. Because the philosophy of planting now reap tomorrow is a process that must be done to form the character of the nation.

\subsection{The Role of Parents in Cultivating Children Attitude}

Planting early values should start from family, which is the first environment for growth of children's characters. In an attempt to shape the character, habits, morals or character of the child, there are a few things that need to be done.

1. Enforce discipline consistently.

a) Limitation norms must be introduced to children. Children should know where its limits are, what his responsibilities are, and what it is not is his responsibility.

b) Children should be invited to make such limitations, not only created by adult. The introduction of limits on the basis of enforcement of discipline so that the child learns behavior is supposed to do and not to do.

c) The older people should have and showing attitude and treatment ajek. When one time prohibit or allow certain behaviors, in another moment when a behavior happen again, should remain on the same attitude (no change). 
2. Engage fully in building the children character.

Parents have desire and engage fully in instilling attitudes in children. So no matter if the parents in her everyday practice anything that will be ditanamkannya to the child. For example, parents want to impart to behave honestly, speak the word politely, as well as responsible. However, if the parents turned out in everyday life is precisely the opposite behavior, showing what would happen with the development of the child's soul? Children will experience confusion, may also be a conflict, because his parents in unconsistently saying and behaving. This is what makes the reasons for children not to do what it wants.

3. Being a good example or model for children. Remember, children tend to imitate behavior of his parents than just listening to the words. That's what parents must also behave in accordance with the precedence values in everyday life. In order to be a positive example or model for a child, there are some things that need to be brought to the attention of parents, of whom:

a) Realize that the values are the basis of all behavior and make yourself as a role model for children.

b) Determine the values that are most appropriate and shows which values should take precedence through activities and experiences everyday. c) Showed a positive, friendly, personalized, and integrated.

d) Confronting the child with full appreciation, love, and understanding.

e) Believes will be the values that best fit to have.

f) Creates a valuable and meaningful experience with, then ask the child about how should have to take a choice or decision.

4. Cultivate the values of virtue in children.

Besides being a positive example or model for the child, to cultivate the virtue of values in children, parents also need to do the following things:

a) Explain to the child who can talk, the reason for the application of moral values in everyday life. Invite children brainstorm so that parents can know his opinion about how much he understands the moral values.

b) Explain to the children about the impact the behavior of both positive and negative. "If you want to keep your child moving their feet on the ground, give responsibility on the shoulders of their" farm. For example, when the child smoothing her toys, parents can say, "son, if dealt with her toys so neat and you will be easier to find the toy you'd like to play." So also when children make mistakes, as he hit his 
sister, saying, "the younger brother so if you cry at."

c) Gave the award to the child, such as praise, a hug, a kiss, a thank you, and others, when children behave positively so that children are compelled to reiterate the positive behavior.

d) Read a fairy tale or story that deals with an act of good/positive. Use simple language that suits the child's thinking ability so that the child can understand and enjoy the story content.

\subsection{The Role of Teachers in Cultivating Children Attitude}

In instilling the attitude to children in school, the teacher has a strategic position as a major offender. The teacher is a figure that can be imitated or becoming an Idol for the child. Teachers can be a source of inspiration and motivation children his protégé. Attitude and behavior of a teacher is marked in the child so that the speech, character, and personality of the teacher, thus the teacher becomes a mirror for the child. Thus, the teacher has a great responsibility in making the character generation, cultured, and immoral. Human tasks it is transformation, identification, and understanding about themselves, which must be implemented together in unity the organists, harmonious, and dynamic. Learner or teacher should have a good understanding of the characteristics of the participants of learning in order to succeed in carrying out the role of teach Eka (2018)
There are a few strategies that can provide opportunities and a chance for teachers to playing its role optimally in terms of development of character education learners in school, as follows:

a) Optimizing the role of the teacher in the learning process. The teacher should not have put myself as an actor who was seen and heard by the children, but the teacher has role as a Director, directing, guiding and facilitating, in the learning process, so that the child can do and find out for yourself the results of his studies.

b) Integrating the material character education into learning. Teacher sued for caring, willing and able to relate the concepts of planting the value in learning materials. Teachers are required to continue to add to the insights of science related to the cultivation of the values, that can be integrated in the learning process.

c) Optimizing the activities of insightful self-conditioning the development of manners and morals. The teachers more emphasis or stress to the development activities of manners and morals contextual noble, activities leading to the development of the ability of the affective and psychomotor.

d) Creating school environment conducively to grow and develop values in children. The environment proved to be very instrumental in the formation of the human person (child), either the environment or the spiritual 
environment. To that end, schools and teachers need to prepare facilities and implementing various types of activities that support the activities of the cultivation of the values in the child.

e) Establishing cooperation with parents and community learners in the development of values in children. The form of cooperation that can be done is to place parents and the community as a resource and facilitator in the value of the planting activities at the school.

f) Becoming a model for the figure of the child. Admission to the materials of instruction given by a teacher, a little to much will depend on the learner's personal acceptance against a private teacher. It's a very human thing, where someone will always try to mimic, imitate what endeared from model/figure. A moment like this is actually a chance for a teacher, either directly or indirectly embeded the character values in the personal selflearners. In the process of learning, character values can be integrated into the substance or subject matter, but also on the process.

The cultivation of the attitude of not merely gives the knowledge of good and bad, but more on fostering awareness and applying will be good and bad values in everyday behavior. Therefore, the cultivation of the attitude should be done in a soft and pleasant. The atmosphere and environment that is safe and comfortable need to be created in the process of cultivation of the attitude of values. To deepen understanding of the expected attitude, the attitude that any value has been incorporated into the learning plan should be applied on an ongoing basis. Planting value attitude continued to be applied in the form of conditioning which are planned by the ECE and mature. Attitude applied to be included in the standard of procedure (SOP) and the daily teaching plan (DTP). For example in DTP listed "pray before and after eating". In RPPH next week "to pray before and after eating" are not listed again, but put in the SOP so that activities to pray before and after meal continues to be applied whenever a child is ahead of and after the meal on a daily basis and all of the year.

\section{CONCLUSION}

Early childhood social attitudes are influenced by three factors, namely, the family, the community and the school. The child's social environment marked by the expansion of the Association. The widespread social environment cause children got influences from the environment of the elderly, particularly with peers, either at school or elsewhere. Social took place on early childhood (0-3 years) subjective, time of crisis (3-4 years) called tort to alter, childhood's end (46) is called subjective towards the objective, time of school children (6-12 years) objective and time of crisis (1213) by any other name i.e. the child responsibility. To achieve the social 
goals of the child should make the new adjustment by increasing the influence of peer groups, changes in social behavior, and social grouping. Parents and teachers have a very important role in the cultivation of moral character or attitude towards early childhood, with planting the right attitude at the early childhood, then it will be able to reduce bullying behaviors in children, will reduce behavior negative in early childhood.

\section{REFERENCES}

Astuti, R. P. (2008). Meredam Bullying (3) Cara Efektif Mengatasi Kekerasan pada Anak).Jakarta: Grasindo.

Ayu, P. E. S. (2018).

MEMBELAJARKAN

KETERAMPILAN

BERKOMUNIKASI SEJAK

DINI. Jurnal Maha Widya

Bhuwana, 1(1).

Coloroso, Stop Bullying (Memutus

Rantai Kekerasan Anak dari Prasekolah Hingga SMU), Jakarta: Serambi Ilmu Semesta, 2003.

Destriyana. (2012). Bullying Tingkatkan Resiko Bunuh Diri pada Remaja. Artikel. http://www.merdeka.com.

Diunduh pada tanggal 2 Mei 2019.

Direktorat Jenderal Pendidikan Anak Usia Dini dan Pendidikan Masyarakat. Kementerian Pendidikan dan Kebudayaan. Penanaman Sikap Pada Anak usia Dini
Elliot, M., Wise Guides Bullying, New York: Hodder Children's Books, 2005.

Fadlillah, Muhammad. 2012. Desain Pembelajaran Paud. Jogjakarta: Ar-Ruzz Media

Gendrowiyono, P. (2013). Pengaruh Pembelajaran Nilai-nilai Toleransi terhadap Ketrampilan Sosial Siswa SMP. Tesis: Universitas Muhammadiyah Surakarta

Liu, J., \& Graves, N, Childhood Bullying: A Review of Constructs, Concepts and Nursing Implications,Public Health Nursing, Vol.28,No.6,hal 556-568, 2011.

Murphy, M. M. \& Bannas, Dealing with Bullying, New York: Chelsea House, 2009.

O'Brennan, L.M., Bradshaw, C.P., \& Sawyer, A.L., Examining developmental differences in the social-emotional problems among frequent bullies, victims, and bully/victims,Psychology in the Schools, Vol 46 No.2,hal 100-115, 2009\

Olweus, D., Bullying at school, Australia: Blackwell publishing, 2004.

Rigby, K., New Perspectives on Bullying, London: Jessica Kingsley, 2002.

Sejiwa. (2008). Bullying: Mengatasi Kekerasan di Sekolah dan di Lingkungan Sekitar Anak. Jakarta: PT. Grasindo.

Slamet Suyanto, Dasar-dasar Pendidikan Anak Usia Dini, 
Yogyakarta: Hikayat

Publishing, 2005

Suhartono, Suparlan. 2013.

Menegakkan Pohon
Pendidikan. Makassar: Badan Penerbit Universitas Negeri Makassar. 